\title{
XXXVII. Further extracts from the first volume of the report to the Board of Agriculture on Derbyshire
}

\section{Mr. John Farey Sen.}

To cite this article: Mr. John Farey Sen. (1812) XXXVII. Further extracts from the first volume of the report to the Board of Agriculture on Derbyshire , Philosophical Magazine Series 1, 39:168, 253-262, DOI: $10.1080 / 14786441208638122$

To link to this article: http://dx.doi.org/10.1080/14786441208638122

曲 Published online: 27 Jul 2009.

Submit your article to this journal $\pi$

Џll Article views: 5

Q View related articles $\sqsubset$ 
Mr. Farey's Account of the Valleys, $\mathscr{0}$ c. in Derlyshire. 253

mon Reflecting Circle; the angle being first taken on one side of the parallelism of the glasses, and then on the other; so that the angle is doubled, then it is repeated on a fresh part of the circle, as many times as the observer thinks proper, and the product divided by the number of observations taken; the mode of taking these observations is explained at full in Dr. Rees's Cyclopædia, and in Dr. Mackay's publication on the means of fiuding the longitude.

XXXVII. Further Extracts from the first Volume of the Report to the Board of Agriculture on Derlyshire. By Mr. John Farey Sen., giving an Account of the principal narrow Rocky VALLEYs, of the Strata intersected and exposed by their Excavalions, and in the most noted Cliffes, Caverns, छீc. therein: of the Cliffs in the wider Valleys, and of the modern SLips or Sliding of Tracts of argillaceous Strata in their Sides, $\mathscr{\odot}^{\circ}$.

$T_{\text {HE Rocky parts of Derbyshire and its environs furnish }}$ numerous instances of narrow Valleys, or Dales (Combes), with precipitous and rocky sides, often exhibiting very fine Rock Scenery, which, as objects of curiosity and interest to the Traveller, seem to require some notice in this place: and being able to mention the most striking particulars, relating to the stratification of each of such Valleys, the following list will, I hope, interest the Miner and the Geologist, as pointing out the best situations for examining and comparing the edges of corresponding strata, on the two sides of a valley, the ledges of Rock in its buttom, and of etudying the truly surprising and powerful causes which have operated, in the excavation of such Valleys; a subject which will be further elucidated, by the account of the beds of the different Rivers*, in Section VI. of this Chapter.

An Alphabetical List of the Names of the principal narrow and Rocky V VLLEYs, or Defiles, with precipitous Cliffs, in and near to Derbyshire, describing their Siluations, the Strata exhibited in their Sides and Bottoms, and the Names of the most noted Rocks, Caverns, E'c. in each.

Barbronk Dale, NE of Baslow, about $\frac{3}{\frac{3}{7}} m$. long, E of Derwent River, in a NE direction; Cliffs and joose blocks of Ist Grit Rock, a lead Cupola, slag-mill and Sulphur work in it.

\footnotetext{
* [This account will be found in my last Number p. 192,-EnITo .]
} 
Beresford Dale, SSW of Hartington, between Derbyshire and Staffordshire, extending about $\frac{1}{4} \boldsymbol{m}$.S, along the course of Dove River, in 4th Lime; ruins of a Castle.

Bonsal Dale, $S$ of the Town, extending nearly W $2 \mathrm{~m}$. from Cromford Town to Griffe and Via-Gellia Dales, with branches on the north up to the Town; 1 st, 2nc, 3rd, and $4 \mathrm{th}$ Lime Rocks, and 1st, 2nd, and 3rd Toadstones, Tufa at Marygrot Spring, Hot Springs formerly: very deep and striking, with a good Turnpike Road through it, towards Buxton: it has two lead Cupolas and slag mills, a Sulphur work, Calamine works, a Stone Saw-mill, \&c. in it*.

Bradford Dale, S and SW of Yolgrave, extending about SW $1 \frac{3}{4} \mathrm{~m}$. from Lathkil Dale; Shale, ist Lime, and 1st Tuadstone (in the River SW of Yolgrave), Slither, or indestructible and barren Lime-rubble on its sides; a prodigious large Sprirg at Middleton.

Bradwell Dale, $S$ of the Village, extending thence $S$ about $\frac{1}{2} m$. in 1 st Lime, with black Chert nodules in very regular layers.

Brock-bottom Dale, NNW of Tideswell, extending about $1 \frac{1}{2} m$. from the Town, 2nd Lime, and and Toadstone (in the Brook at its NW end); Black Marble of the end Lime Rock is dug here, an ebbing Well formerly; Road through it, towards Chapel-en.le-Frith.

Burbadge Dale, NNE of Nether Padley, extending NNE about $\frac{3}{4} m$. in 1st Grit, with Mill-stone Quarries.

Callenge Dale, SE of Monyash, a branch from Lathkil Dale S, ist Lime, Slither.

Cave Dale, SW of Castleton, extending $1 \mathrm{~m}$. from the Town, 3rd Lime, 3rd Toadstone, and 4 th Lime at its E end; a very narrow entrance from the Town, columnar Toadstone.

Combs Dale, S of Stoney Middleton, extending from near Calver WSW about $1 \frac{1}{1} \mathrm{~m}$., deep, in 1 st Lime, and Toadstone at High field Sough-mouth.

Cressbronk Dale, SE of Litton, extending about $1 \frac{1}{2} m . \mathrm{N}$ from the Wye at Monsal Dale; 1st Lime, and 1 st Toadstone at $\mathrm{N}$ end ; and Lime, and and Toadstone, and 3rd Lime at $\mathbf{S}$ end; Slither, Hobsthrust Rocks.

Cresswell Crags, E of Elmton, between Derbyshire and Nottnghamshire, extending $\mathrm{E}$ ahout $\frac{1}{3} \mathrm{~m}$. in a lifted part of the yellow Lime $t$, small Caverns.'

* [Mention of the effects of a great Fanlt on the Strata in this dale, will be found in page 39 of the present volume.-EDrror.]

+ [This is now supposed, an upper Rock; see my present vol. p. 105.-Eq.] 
Cummins Dale, $\mathrm{E}$ of Buxton, extending from Dale-end Mill on the Wye about $\frac{3}{4} m$. NW, 4 th Lime, / with a crystallized granular bed of Limestone on S side ; a dry dale, owing to the Swallow-holes at Water-swallows above.

Deep Dale, $\mathbf{N}$ of Briarley-foot Toll-Bar, near Chelmerton, extending about $\frac{1}{2} m$. SSW from Marl Dale, 4 th Lime.

Devil's Bowling-alley, $\mathbf{N}$ of Alderwasley, extending from the Derwent $\frac{1}{3} \mathrm{~m}$. SW, ist Grit, with large loose blocks.

Dimins Dale, NW of Sheldon, extending from near the Wye River SW about $1 \frac{1}{4} m$., ist Lime at $S W$ end, 1st Toadstone, and and Lime.

Dove Dale, NNW of Thorpe, hetween Derbyshire and Staffordshire, extending northward near $5 \mathrm{~m}$. along the course of the Dove, surprisingly deep in the 4th Lime, much Slither, but no loose blocks : the high and isolated Rocks in this grand dale are called Dove-dale Church, Lover's-Leap, Pickerings, Sugar-Loaves, Tissington-Spires, Thorpe-cloud (at the 5 end), \&c. Reynard's Hall, and Cave, and Dove-hole, are curious Caves; there is here also, a fine natural Arch at Reynard's Hall: many very wide and barren or dead Veins cross this dale obliquely.

Dovehole Dale, NE of Fairfield, extending about $1 \frac{1}{4} m$. NNW from Great-Rocks dale, in 4 th Lime, a dry dale, owing to Swallow-holes at Dove-hole Cotton-mill.

Eyam Dale. See Middleton Daie.

Flag Dale, SW of Wormhill, extending about $1 \mathrm{~m}$. NW from the Wye River at Chee Tor, in 4 th Lime, with 3rd Toadstone along its NE border; large Springs at its SE end.

Grange-mill Dale. See Griffe Dale.

Grass Dale, NE of Wormhill, extending about $1 \mathrm{~m}$. NNW from Monks Dale to Hay Dale, 3rd Lime at $S$ end, 3rd Toadstone, and 4th Lime at $\mathrm{N}$ end ; a dry dale, owing to Swallow-holes in this and Hay Dale above.

Great Rocks Dale, $W$ of Wormbili, extending $2 \frac{\pi}{2} m$. from the Wye NNW to Dovehole Dale, in 4 th Lime, with sunk pieces of 3rd Toadstone in it? near the Buxton Road; a dry dale, owing to the Swallow-holes at Dovehole Cotton-mill above.

Griffe Dale (cr Grange-mill Dale), S of Grange Mill, extending thence south $x$ ard about $1^{3} m$. to Via-Gellia and BonsalDales, in 4 th Lime, Jrd Tuadstone at its $\mathrm{N}$ end; a new Turnpike Ruad throngh it.

Hamps Dale, in Staffordshire, NNE of Caldon, extending $\mathrm{R} 4$ about 
ahout $2 \frac{1}{4} m$. SSW from Ilam and Wetton Dales at Beaston Tor, in 4 th Lime. The channel of the Hamps River is here dry, when not swoln by great rains, and its waters, which fall into Swallow-holes at Waterfall and Waterhouses, pass more than $3 \mathrm{~m}$. under ground to Hamps Spring! W of Ilam Hall.

Hay Dale, $\mathrm{S}$ of Peak Forest Town, extending about $1 \mathrm{~m}$. $\mathrm{N}$ from Grass Dale, in 4 th Lime; a dry dale, below the Swallow-holes near,its $\mathrm{N}$ end.

Hav Dale, $S$ of Wardlow, extending $N$ about $1 m$. from Monsal Dale, in 2nd Lime, with 1st Toadstone at its $\mathbf{N}$ end, and nearly along its eastern border; vast beds of Slither, or indestructible and barren Lime-rubble, on its E side.

Hipple Dale, W of Brassington, extending about $\frac{\pi}{2} m$. NNE, with a branch $\mathrm{E}$, in 4 th Lime; a prodigious Spring hreaks out at its 'S end, near the great Limestone Fault, about once in 20 years.

Ilam Dale, in Staffordshire, NW of the Town, extending thence near $3 \mathrm{~m}$. to the Hamps and W.etten Dales, 4th Lime. The channel of the Manifold River is here dry in dry seasons, owing to the vast Swallow - holes at Darfa Cliff, Waterfall and Waterbouses above, until the great Hamps and Manifold Springs break ont, in and near to Ilam Gardens ; Beaston Tor Rock at its NW end.

Lathkil Dale, $\mathrm{N}$ and $\mathrm{E}$ of Yolgrave, extending from near Stanton to near Monyash about $5 \frac{\mathrm{I}}{2} \mathrm{~m}$.; Shale near Alport, 1st Lime, 1st Toadstone and 2nd Lime $S$ of Over Haddon, Tuta at Alport, Slither, Raventor Rock near Alport.

Marklind Grips, NE: of Elmton, extending NE about $\frac{s}{4} m$. to Cressivell upper Mill, in yellow Lime.

Marl Dale, NW of Chelmerton, extending SSW about $11 \mathrm{~m}$. from the Wye River to Deep Dale, 4th Lime; a large Cavern.

Matlock-Bath Dale, SW of Matlock, extending nearly N along the course of the Derwent River more than $2 \mathrm{~m}$. fromi Cromford Cotton-mills; Shale S of High Tor, 1st Lime, ist Toadstone, 2nd Lime, and 2nd Toadstone at font of the High Tor; Tufa, Petrifying Springs, Hnt Springs, and Baths; High Tor, Scarthen Cliff, and Wildcat Tor Rocks, \&c. Cumberland Cavern : a good Turn. pike Road through this beautiful dale, towards Bakewell. (See the Section in Plate V.*)

* [See plate II. in my 31 st volume; and further particulars of its Stratz in the present volume, page 195.-EDITol.

Meadow 
Meadow Dale, $\mathbf{S}$ of Tideswell, extending $\mathrm{W}$ about $\frac{1}{2} m$. trom Tideswell Dale; 3rd Lime, and 3rd Toadstone at its $\mathrm{E}$ end.

Middleton (or Eyam) Dale, $W$ of Stoney Middleton Town, extending thence about $1 \frac{3}{4} \mathrm{~m}$. W, ist Lime, deep and romantic, with several deep collateral branches; Castle, High Tor, Steeple, and Lover's Leap Rocks ; Bamford, Charleswark, and Merlin's Caverns : a Lead Cupola and slag mill, and Sulphur work; a good Turnpike Road passes through this curious dale berween Tideswell and Sheffield.

Mill Dale, $E$ of Buxion, extending about $\frac{3}{4} m$. NW from Sherbrook and Wye Dales, 3rd Lime at its NW end, 3rd Toadstone and 4 th Lime, white Marble, (Tufa); a good private Coach-road through this dale.

Mill Dale, in Staffordshire, S of Alstonfield, extending W $a^{\text {bout } 1 ~} \mathrm{~m}$. from Dove Dale; deep and rugged, in 4 th Lime.

Millers Dale, SE of Wormbill, extending W about $1 \frac{1}{2} m$. along the course of the Wye River, from Monsal Dale to Wye Dale and Sandy Dale; 3rd Lime, with and Toadstone and 2nd Lime skiring its $S$ border and parts of its $\mathbf{N}$ burder; the ard loadstone appears in the River, about its middle and at its W end, Tufa. Ravens Tor, and other bold and high Rocks skirt this dale.

Monks Dale, $\mathrm{E}$ of Wormitill, extending NNW about it m. from the Wye at Millers Dale to Grass Dale: in 3rd Lime, the 3rd Toadstone seen at its $\mathrm{N}$ end, where the Buxton and Tideswell Road crosses it, and the 2nd Toadstone skirts both sides of it at the $S$ end: Tufa is found in it at the $S$ end; a dry dale, owing to Swallow-holes in Hay and Grass Dales above.

Monsal Dale, NW of Ashford, extending about NNW by a crooked course (along with the Wye River) of about $2 \frac{3}{4} \mathrm{~m}$. from the W face of Fin Copt Hill to Millers Dale; in and Lime, and Toadstone, and 3rd Lime at its northern end, having the 1st Toadstone and lst Lime on its eastern skirt at the southern end, and the 2nd Lime along all its western skirt or border: much Slither, or indestructible and barren Lime-rubble is lodger on the sides of this valley; black Marble of the 2nd Lime is dug here, near Little Longsdon.

New-Mills Dale, $\mathbf{S}$ of the Village (in Glossop), between Derbyshire and Cheshire, extending about $W_{\frac{1}{3}} \mathrm{~m}$. from the junction of New-Mills Brook with the Goyte River, in 3rd Grit and Coal Shale, called Tor Cliff. This is the 
most singular and striking Grit-stone Valley, which I have any where witnessed.

Plesley Forge Dale, E of the Town, between Derbyshire and Nottinghamshire, extending $E$ about $\frac{\pi}{2} m$. in yellow Lime. Hobstlirust and other bold Rocks are here much admired; a large Cotton-mill occupies the site of the ancient Iron Forge.

Ricklow Dale, $\mathrm{E}$ of Monyash, extending nearly $\mathrm{N}$ about $\frac{1}{3} m$. in Ist Lime; Entrochi Marble is here dug.

Sandy Dale, SSE of Wormhill, extending SSW about $\frac{3}{4}$ $m$. from Wye Dale to near Blackwell Village, in 3rd Lime, and 3rd Toadstone at its southern end: the and Toadstone skirts its eastern border at the northern end, and produces numerous quartz Crystals, or Derbyshire Diamionds.

Sherbrook Dale, SE of Buxton, extending nearly SW about $1 \frac{1}{4} m$. from $W y e$ and Mill Dales, in 4 th Lime, and a patch of $3 \mathrm{rd}$ Toadstone, at the crossing of the Buxton and Ashburne Road, whence a private Coach-road proceeds through this dale eastward.

Small Dale, SW of Peak Forest Town, extending NE about $\frac{1}{2} m$. from Dovehole Dale, in 4th Lime, which on the sides of this dale assumes a columnar structure.

Thaich Dale, $W$ of Wheston, near Tideswell, extending $\mathrm{E}$ about $\frac{1}{3} \boldsymbol{m}$. from Grass Dale, 3rd Lime and 3rd Toadstone; 4 th Lime on its $\mathrm{N}$ skirt.

Tideswell Dale, $\mathrm{S}$ of the Town, extending therefrom $1 \mathrm{~m}$. to Millers Dale, in 3rd Lime, and 3rd Toadstone which is thrown up therein by a Fault: the 2nd Toadstone skirts along near its $E$ border; Tufa is found in it, at its $S$ end. It is often a dry dale, owing to the Swallowholes at the $\mathrm{S}$ end of Tideswell Town.

Via-Gellia Dale, $N$ of Hopton, extending about $\frac{8}{4} m$. $S$ from Bonsal and Griffe Dales, in 4th Lime. The Hopton-wood Freestone Quarries are on the E side of this Dale, just below the 3rd Toadstone basset. Mr. Gell's private Road passes through this Valley.

Whaley Furnace Dale, $\mathbf{N}$ of Over Langwith, extending about $\frac{3}{4} m$. nearly $\mathbf{N}$, in yellow Lime.

Wensley Dale, $\mathrm{S}$ of the Village, extending $\frac{1}{2} m . \mathrm{ESE}$, in 1st Lime.

Wetton Dale, in Staffordshire, W of the Town, extending nearly $\mathrm{N}$ about $1 \frac{\mathrm{I}}{2} \mathrm{~m}$. from Hamps and Ilam Dales; deep in the 4th Lime. Thor's House Tor is a remarkable Rock with a natural Arch and Cave, by this Dale, which is dry in dry seasons, below Darfa Swallow-holes, which 
suddenly absorb this considerable River, after it has crossed the great Limestone Fault*.

Winnets Dale, $\mathrm{W}$ of Castletun, extending about $\frac{1}{2} \mathrm{~m} . \mathrm{W}$, in 4 th Lime, deep and rugged; the Turnpike Road to Chapel-en-le-Frith goes up this steep and curious valley. Wirksworth Dale, in NW end of the Town, extending NW about $\frac{1}{3} m$. in 3 rd Lime.

Woo Dale, $\mathrm{E}$ of Buxton, exceeding $\mathrm{N}$ about $\frac{8}{4} \mathrm{~m}$. from Wye Dale, in 4th Lime.

Wye Dalet, $\mathrm{E}$ of Buxton, extends $\mathrm{E}$ about $4 \mathrm{~m}$. from Mill and Sherbrook Dales to Millers Dale, in 4th Lime, and 3rd Toadstone at its $\mathrm{E}$ end, the 3rd Lime there also skirting it on each side. Chee Tor, Peterson Pike, and Lover's Leap, are noted Rocks in this Dale, which has some Slither in it, particularly opposite to Chee Tor in Wormhill, where are two very large Springs of Water. The Duke of Devonshire has, I have been informed, a design of extending the private Ruad for the accommodation of Travellers, from Lover's Leap at the SE end of Mill Dale, through Wye Dale, Millers Dale, and Monsal Dale to Ashford, by which all the Hills between these places, and indeed all those between Buxton and Matlock nearly, would be avoided, besides laying open the fine Rock scenery on the Banks of the Wye River, which has hitherto been but little seen, owing to the great difficulty of access to it.

I have selected the above, as specimens of the narrow and precipitous Valleys of Derbyshire and its environs : the neighbourhoods of Ballidon, Brassington-pastures, Brushfield, Dowall, Flagg, Hartington, Pike-Hall and others, present similar Dales, snme of considerable length, and not less striking than many of the above, and which I have visited, but don't happen to have learnt their particular Names; otherwise they would have been included, on account of the facility which such Lists give, of recording a number of highly curious and interesting phænomena, of which Travellers may in future avail themselves: it is to such Valleys also, that Mineralogists and Geologists must principally resort, to become acquainted with the different Calcareous and Basaltic Rocks of this County, to draw materials for the Natural History of each, and for settling

* [See page 32 of the present volume.-EDITOR.].

+ Sometimes the term Wye Dale is used, to designate the entire Limestone Valley from Buxton to Bakewell, in which sense, it includes Mill Dale, Millers Dale, Monsal Dale, \&c.- -See further particulars of the strata in these Dales in the present volume p. 198. 


\section{$260 M r$. Farey's Account of the Slips in Strata, \&o c.}

the important and contested questions, respecting the origin, and mode in which Valleys were excavated and formed.

It must nat be inferred, that high and precipitous Rocks and Cliffs are peculiar to or confined to the class of Valleys of which I have been speaking, since the sides of the wide Valleys, also, abound with Rocks and Cliffs, some of them highly picturesque and beautiful, but such Rocks seldom continue far, without the intervention of grassy or cultivated slopes, such as the sides of Valleys usually present, in districts where no durable or permanent Rocks exist in their strata: whereas, in the narrow Valley's above, such slopes, or interruptions to the continuity of the Cliffs on each of their sides, are rare, and in some instances do not occur at all, within the distances which I have named. The Grit-stone Rocks of this district, seem particularly disposed to appear and disappear repeatedly on the surface at their edges, or in tracing their Bassets through the country; and except of the 1st or lowest Grit Rock, it is a rare thing to find a continued Grit-stone Cliff of any length : some of them, indeed, are so disposed to moulder and fall, on exposure to the air, rain, frost, \& $\mathrm{c}$. that Cliffs of such Rocks are never seen; but where Slips or slidings have happened, in comparatively modern times, of which there are numerous and striking examples in Derbyshire, particularly in the Shale and shale Grit districts; and as it seems of the utmost importance in Geological researches, to distinguish between Cliffs or Facades of equal antiquity with the Valleys themselves, probably, or such as have originated with, or been increased by, subsequent and sudden Slips*, or by the gradual and recent undermining of currents of the Brooks and Rivers, I shall here give a

List

- Since the above was written, I have read with some surprise, pages 61 and 62 of the recent Translation of M. Werner's "New Theory," on the subject of Mineral Veins, wherein the phenomenon of Slips, as above, is described, and it is gravely maintained, that such, bappening " in rainy seasons," have opened the fissures for Mineral Veins (to be afterivards filled, I supposed); as though the conchoidal fracture of a Slip from an adjoining Fill, close pressed and ground by the moving load of softened Earth, had any relation to a rake Vein! This is not however solely relied on for the opening of Veins; but we are informed (p. 48), that while the beds of the Mountains were "at first wet, and possessed little solidity" the mass " yielded to its weight," " sunk and cracked," "falling to the free side;" now, not withstanding the parade of mathematical definitions and preparations, at pages 88 and 89, I would venture to ask any one who knows Derbyshire, and the large rake Veins which cross the comparatively flat districts, that lay between Hradwell and Tide:well or Wardlow, between Sheldon and Monyash, between Winster and Bonsal, \&c. which is the free side in any of these cases? or what sort of an action of their uwn weight it must have been, which caused such immense lumps of Limestone to start a few feet asunder, in sa 
List of such SLIPs, or modern sliding and sinking of tracts of ground on the sides of Hills, as I have noted in the course of my Survey, viz.

Alpert, in Hope Woodlands (Castles).

Atlow W, Win House SE, recent.

Bakewell, $S$ of the Town; and E (Edge).

Bramcote E, Staffordshire (Black-Meer of Moredge).

Bretton NE, in Eyam (clough).

Calver S, in Back Dale (North Cliff).

Castleton NW (Mam-Tor Hill S side, large).

Charlesworth, in Glossop, NE (Hargate Hill), and SE (Combs Rocks), in 2nd Coal Shale.

Darley N (Stone Cliff): and S (Oaker Hill).

Darwent Chapel SE (Shuts ding Bank, and Lady-bower); N (Hag-hole): and NNW (Ronksley).

Edale, in Castleton (Mam-Tor Hill NW and NE sides), very large: (Back Tor, of Lose Hill $\mathrm{W}$ end); and Lee Farm.

Great Hucklow N (Bur-Tor).

Haddon Park W, in Bakewell.

Hathersage $\mathrm{E}, \mathrm{N}$ of the Cupola.

Lea, near Matlock, SW (Woodseats): and (White Tor). Ludworth, in Glossop, NE (Stirrup Benches), in 2nd Coal Shale.

North Anston, Yorkshire, N (Clarkes Stones) in yellow Lime, \&c.

Rowlee, in Hope Woodlands, $N$, very large.

Stamington, near Sheffield, Yorkshire (Little - Matlock Cliffs), in ist Coal Shale.

Stanton Leys, near Darley, N (South Moor).

Starkholmes, in Matlock.

Tor-side, in Glossop, near Woodhead.

many instances, quite down to the Toadstone (and again under it, as some would remind them)? It is just hinted to us, it is true (p. 50), that "t the shrinking of the mass of a Mountain, produced by desiccation, and still more by Earikquakes, and other similar causes, may also have contributed to the formation of rents," for Veins. As a comment upon all this, the learned Translator tells us, truly, I believe, (p. 256) that "the widest Veins generally occur in the most horizontal strata." Since the above, Dr. James Millar, in his Appendix, to Williams's Mineral Kingdom, professing to give a view of the "Theory of Werner," omits all notice of the opening of Mineral Veins by Slips, Pressure, Earthquakes, \&ce. as above, and merely says, that they happened, according to this Theory, "by the drying and shrinking of the newly formed strata."-Perhaps the Doctor chose this course, out of ten. derness to the author of the Theory.

* [Mr. F. informs me, that 2 large and curious slip at Overton $\frac{\mathrm{r}}{2} \mathrm{~m} . \mathrm{S}$ (Raven's Nest Tor) in Ashover, has been omitied above.-EDtrox.] 
Upper Ashop, in Hope Woodlands, NW (Combs-Tor), very large; (Dine-Sitch Tor): and N (Collet Hay).

Wensley, near Winster, $N$.

Willersley, in Matlock, NE.

Wirksworth, NW (Bole-Hill).

Woodhead, Cheshire, SE.

Woodseats-Hall, in Barlow, $\frac{1}{2} m$. SW, in and Coal Shale.

All the above Slips, except five, which are mentioned, and numerous other smaller ones, are occasioned by the Limestone Shale; sometimes the sunk pieces contain part of the 1st Grit Rock on the Shale, or large pieces of shale Grit, or shale Limestone, perhaps, in their masses.

As in the judgement of some I shall be thought, probably, to have said too much already on the form and surface of the County, I shall now close this Section by mentioning, that Derbyshire contains about 972 square English miles, or 622,080 statute acres $\%$.

XXXVIII. Description of an inclosed Grindstone, intended to prevent prejudicial Effects to the Persons employed in pointing Needles. By Mr. Thomas Wood $\uparrow$.

Srr, I herewith submit to the inspection of the Society instituted for the Encouragement of Arts, \&xc. a model of an inclosed grindstone, intended to prevent prejudicial effects to the persons employed in pointing needles.

This grindstone is inclosed in a case of word or metal, and hath a hood wherein a square of glass is inserted, designed to admit light on the articles under operation.

The particular advantages attending a grindstone suspended in this manner, with a hood and a damp cloth, are, that the stream or current of air, formed by the motion of the stone on its axis, is confined by the case under the hood of

* Which is the result of a careful scaleing of my large Map. In the Original Report, Mr. Thomas Brown stated the quantity at 720,640 acres; the Parliamentary Returns of the Poor's Rates, as stated by Mr. Thomas Puole, make Derbyshire contain 689,280 acres, which last, considering that many of the Parish quantities must have been stated by estimation, agtees sufficiently near with mine above. About the year 1756, when Benjamin Martin published his Natural History of England, this County was stated to contain only 540,800 acres; but a Dictionary of Arts and Sciences, now pubiishing in London, magnfies its dimensions to 1,600.000 acres! See other particulars ot the acres in this County, in Sections IV. and VI. of this Chapter.

+ From Trunsalisons of the Socteiy for the Encotragement of Arts, Mamufoctures, and Commerce, for $18: 1$. The silver medal of the Society was voted to Mr. Wood for this invention, and a model of the Apparatus is preserved in t'se Suciety's Repository. 